\title{
THE PUBLIC LIBRARY AS SEEN BY THE NON-USERS
}

\section{La biblioteca pública vista por las personas no usuarias}

\author{
Mireia Fernández-Ardèvol, Núria Ferran-Ferrer, Javier Nieto-Arroyo and \\ Carme Fenoll
}

Nota: Este artículo se puede leer en español en:

http://www.elprofesionaldelainformacion.com/contenidos/2018/may/19_esp.pdf

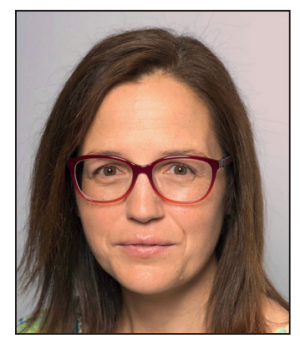

Mireia Fernández-Ardèvol, PhD, is a senior researcher at the IN3-UOC. Since 2003 she has studied the influence of mobile communications in our societies from a socioeconomic perspective. She develops research on the way digital technologies shape, and are shaped, by users. With a background on Econometrics, she is an expert in quantitative techniques in the field of Social sciences. http://orcid.org/0000-0002-6938-1943

IN3 - Internet Interdisciplinary Institute
Universitat Oberta de Catalunya
Av. Carl Friedrich Gauss, 5. 08860 Castelldefels (Barcelona), Spain
mfernandezar@uoc.edu

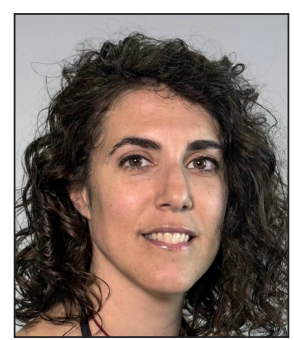

Núria Ferran-Ferrer is an associate professor at the Faculty of Information and Communication Sciences, Universitat Oberta de Catalunya (UOC) since 2005. She holds a European Ph.D. in Information Science (Universitat de Barcelona, $U B$ ), a master degree in Information society (UOC) and bachelors in Information Science (UOC) and Journalism (Universitat Autònoma de Barcelona, $U A B)$. She is researching the youth political participation in social media and the experiences of ageing with the new forms of communications in networked societies.

http://orcid.org/0000-0002-9037-8837

Universitat Oberta de Catalunya Estudis de Ciències de la Informació i de la Comunicació Av. Tibidabo, 39-43. 08035 Barcelona, Spain nferranf@uoc.edu

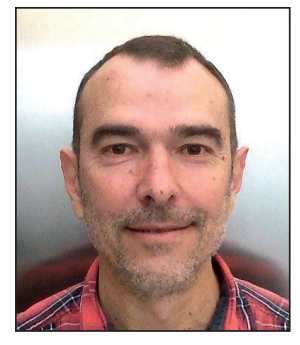

Javier Nieto-Arroyo is a librarian at Generalitat de Catalunya since 1989. Currently he is the responsible person for statistical tasks in the Catalan Library Service since 2005. In addition to collection, exploitation and evaluation of statistical information of the libraries of the Public Reading System of Catalonia, he also develops his activity in the field of standardization and planning of the public library services.

http://orcid.org/0000-0002-7533-2611

Generalitat de Catalunya, Departament de Cultura Servei de Biblioteques PI. Salvador Seguí, 1-9. 08001 Barcelona, Spain jnietoa@gencat.cat

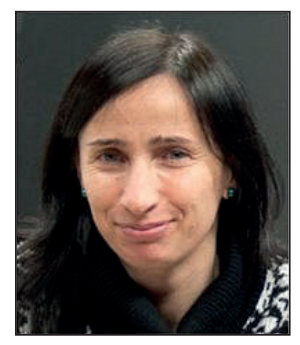

Carme Fenoll, diploma in Library and Information Science, and bachelor in Documentation, was the director of the Palafrugell Public Library, Girona, Spain, from 2000 to 2012. From 2012 until March 2017 she was the head of the Libraries Service of the Departament of Culture of the Generalitat of Catalonia. At the end of 2017 she joined the board of directors of the Polytechnic University of Catalonia as the head of the rector's office.

http://orcid.org/0000-0001-6287-4895

Universitat Politècnica de Catalunya, Gabinet del Rector Jordi Girona, 31, Edifici R (Rectorat), PI. 3. 08034 Barcelona, Spain carme.fenoll@upc.edu 


\begin{abstract}
The user experience framework (UX) serves to analyze the characteristics, preferences and perceptions of non-users of the public library to inform the (re)design of services. Empirical data come from a representative survey of the Catalan population aged 15 and over. In general terms, libraries and librarians benefit from a positive image, although one third of non-users would have no motivation for visiting a public library (again). Most are ex-users (81\%) who had visited a public library but not in the last year. Individuals seem to stop using the public library when they end their educational period, with disengagement affecting more men than women. Never-users (19\%) stand out among older individuals and lower educational levels. Results support the idea that different strategies must target ex-users and non-users to attract them (back) to the library as both their profiles and opinions on the public library are different.
\end{abstract}

\title{
Keywords
}

UXLib; User experience; UX; User centered design (UCD); Public libraries; Users; School libraries; Non-users; User research studies; Survey.

\section{Resumen}

En el marco de la experiencia de usuario (UX) analizamos las características, preferencias y percepciones de las personas no usuarias de bibliotecas públicas para apoyar el (re)diseño de sus servicios. Los datos empíricos provienen de una encuesta representativa de la población catalana de 15 años o más. Las bibliotecas y sus profesionales cuentan con una imagen positiva, si bien un tercio de las personas no usuarias no visitaría una biblioteca pública (de nuevo). La mayoría son ex-usuarios (el $81 \%$ había visitado una biblioteca pública pero hace más de un año). Al terminar el período educativo también acaba la relación con la biblioteca, una tendencia más acusada en el caso de los hombres. Las personas que nunca han sido usuarias (19\%) destacan entre la población mayor y en los niveles educativos más bajos. Es necesario que las estrategias de la biblioteca para incrementar el uso sean diferenciadas en respuesta a los perfiles y opiniones sobre la biblioteca de las personas ex y no usuarias.

\section{Palabras clave}

Experiencia de usuario (UX); Diseño centrado en el usuario; Bibliotecas públicas; Bibliotecas escolares; Estudios de usuarios; No-usuarios; Encuestas.

Fernández-Ardèvol, Mireia; Ferran-Ferrer, Núria; Nieto-Arroyo, Javier; Fenoll, Carme (2018). "The public library as seen by the non-users". El profesional de la información, v. 27, n. 3, pp. 659-670.

https://doi.org/10.3145/epi.2018.may.19

\section{Introduction}

Public library main goal is to provide services and resources in a variety of media that meet the public's needs (IFLA, 2001) with equal opportunities for everyone (Unesco, 1994). Libraries are collections and buildings, but above all, libraries exist for the community (e.g. Anglada, 2014). As "libraries are about people, not books" (Booth, 1993, p. 14), there would be no library without patrons. The characteristics of both patrons and non-users of the library, their motivations for (not) approaching the library, and their preferences and expectations constitute essential data for understanding the perceptions of current services, and for improving them or creating new ones (Connaway, 2015; Schmidt; Etches, 2014; Juárez-Urquijo, 2015).

We approach the analysis of the relationship between citizens and public libraries from the user experience (or UX) framework. UX encompasses all aspects of the end-user's interaction with the company, its services and its products (Norman; Nielsen, 2014). This term originally referred to interactions or exchanges with electronic devices, and nowadays is widely applied to evaluate both digitally mediated and face-to-face interactions. Moreover, UX is a critical factor for success as it is linked to the quality of the experience the user obtains through products and services (Nieters; Gabriel-Petit, 2014).
The UX design clearly distinguishes between (actual or potential) end users -people who use a product or a service- and the intermediaries who enable users to interact with the product or service. In libraries, librarians are the intermediaries between the institution and the citizens - the users. Librarians therefore are not users, and despite their knowledge and their continuous contact with users, they do not necessarily know their specific needs (Gallo-León, 2015). Determining user requirements is essential for designing appropriate products and services, but designs limited to the intermediaries' opinions and perceptions of users should be avoided (Norman; Nielsen, 2014). The UX design helps to improve services from the point of view of users and potential users. From the UX perspective, patrons do not go to the library to find books, magazines and CD but in seek of experiences, to find solitude or company, to enjoy themselves, or to learn (Reidsma, 2015). In this sense, the user research phase is critical in obtaining information related to characteristics, preferences, desires, opinions and perceptions of (potential) users (Sundt, 2017). It allows designing and redesigning higher-quality experiences for end users and attracting new ones (Johnson et al., 2015). Of importance in UX design are the perceptions and opinions of potential users, an innovative approach when it comes to analyze the public library -as they tend to analyze current users. 
As for this research, a user -or patron- is the person who has visited the library at least once in the previous year ( $T e$ chnical Committee ISO-TC 46, 2014). We depart from institutional definitions (e.g. Departament de Cultura, 2017) and studies (e.g. DIBA, 2012) that identify affiliation cards with actual users for a more suitable, flexible approach. Not all cardholders are active users while visiting the public library does not require formal affiliation.

We define two categories of non-users:

- ex-users are individuals that say who had visited the public library at some point but not in the last year; and - never-users are individuals that say who have never visited it.

Ex-users had been involved with the library but are currently disengaged, while never-users have never engaged with it.

The paper originality is based upon the study of a user research performed to non-users in the case of the public library. Techniques for user research studies are implemented to non-users focusing in two particular aspects related to the UX experience: the image of the library and the librarians, and the factors that would help in engaging them with the library. An analysis of the socio-demographic characteristics of users and non-users will help identifying the populations public libraries should target as potential users. Data come from a representative survey of the Catalan population that mainly focuses on non-users, which to our knowledge, constitutes the first study applied to public libraries in Catalonia.

\section{Context}

Catalan public libraries have 3.7 million of registered users accounted in terms of membership cards- and receive 24.9 million of visits per year (Departament de Cultura, 2017). By law, municipalities with 5,000 or more inhabitants must have a public library (Llei 4/1993). The regular public library is complemented with a mobile service called "bibliobús", which together cover the $94 \%$ of the Catalan population and offer an interlibrary loan service at a country level (Servei de Biblioteques de la Generalitat, 2017). Defined as main community cultural centers (Azqueta; Ferrández, 2015), they are consolidated agents capable to contribute to social transformation at the local level (Togores, 2014). Almost one in two adults in Catalonia define themselves as users $(47 \%)$ and rate the public library very positively -8.1 points out of 10 (CEO, 2015). There has been an increase in registered users between 2011 and 2015, but a stagnation in visits and borrowed documents (Departament de Cultura, 2017), together with a slight reduction in the individuals who visit the library at least once a year (Conecta, 2016).

Women are more likely to be users than men, and library usage substantially declines with age and is strongly linked with being in full-time education -see Quick; Prior et al. (2013) for 17 EU countries, CEO (2015) for Catalonia, or Horrigan (2016) for the US. In the US the use of public libraries also depends on being in school age, with education playing a more relevant role than income. However, disadvantaged populations, including ethnic minorities, recent immigrants and people with disabilities were less likely to be users in all the cases (Sin; Kim, 2008). Beyond these three representative surveys, librarians reported different socio-demographic profiles of non-users in Rome, with a lack of younger teens and pensioners, and Manchester, where older teens and young adults are the most missed groups (Sbaffi; Rowley, 2015).

Motivations for non-use relate to lack of time (Schleihagen; Ehmig, 2012; Evjen; Auduson, 2009), the perception that the service is not needed (Consonni, 2010; Schleihagen; Ehmig, 2012), and the pervasive presence of Internet as a faster source for getting resources (Consonni, 2010; Schleihagen; Ehmig, 2012; Sin; Kim, 2008). In addition, the lack of knowledge about the library services increase non-use (Toner, 2008). Finally, among young people in the UK, most common reason for not visiting the library was the lack of habitude within the family, with significant differences in dimensions as gender, age, ethnicity and socioeconomic background (Clark, 2010).

The traditional image of the library is attached to books and, through them, to culture (Anglada, 2014). Libraries have more services and objectives than what the public usually identifies (Levien, 2011). This increases the psychological distance to the library -traditionally considered a barrier to use (Booth, 1993), which is different for users and nonusers, as they have different images of the public library (McCarthy, 1994; Quick; Prior et al., 2013). Same is valid regarding the image of librarians and the stereotypical assumptions around their job (Luthmann, 2007). A literature review found that negative perceptions prevail and their work is misunderstood (Vassilakaki; Moniarou-Papaconstantinou, 2014). Particularly, the emotional factor attached to the personal relationship with (potential) users is of relevance (Consonni, 2010; Coker, 1993;). Overall, the use of the library is directly related with the images and perceptions that individuals and library funders hold of libraries, library services and the librarian profession (Green, 1994; Coker, 1993). Coker states that it is not only negative images and perceptions that need to be overcome but also barriers caused by lack of awareness of the "library world" and unrealistic expectations.

\section{Method}

The representative survey of the population of Catalonia aged 15 years old and over was conducted in late 2015 (Ferran et al., 2016). The questionnaire, with a maximum length of 15 minutes, was administered as a computer assisted telephone interview (CATI). The sample size totaled 1,205 individuals, and a random sampling process guaranteed a margin of error of $+/-2.8 \%$, assuming a confidence level of $95 \%$ in a situation of maximum uncertainty $(p=q=0.5)$. We established quotas by age, sex, province and municipality size that also serve to guide the analysis. Following CEO (2015), and with the aim of treating each subsample independently, we also aimed at reproducing the structure of users (47\%) and non-users (53\%) in the adult Catalan population but we did not apply a strict quota because our targeted population included teenagers. The final sample splits into $56 \%$ users and $44 \%$ non-users of public libraries (669 and 536 respondents, respectively) and the dimension of each subsample guarantees usually accepted levels of error (+/-3.8\% and +/-4.2\% respectively). 
Univariate and bivariate techniques (Hair, 2010) serve to analyze the structured data. In addition, we coded the openend question on the image of librarians ("What image does the profession of librarian suggest you?"): First, we took a grounded approach (Bryant; Charmaz, 2007) for initial coding. Secondly, we discussed and agreed the analytical categorization based on the previous step, and used it for the quantitative analysis. In the following sections we discuss selected results in aggregated terms and, when appropriate, in terms of individuals' socio-demographic characteristics. We also look for particular trends regarding ex-users and never-users. Reported results focus on statistically significant differences at a $5 \%$ level. Data refer to the population aged 15 years and over living in private households in Catalonia.

Men qualify as ex-users more than women (40\% vs. $33 \%)$

\section{Who does and who does not use public libraries}

With $56 \%$ of the sample being patrons, the remaining $44 \%$ split into ex-users and never-users. Ex-users represent the majority of non-users ( $81 \%$ ) and one third (36\%) of the total population. Never-users are the $19 \%$ of the non-users and the $8 \%$ of the total population.

As Figure $1^{1}$ shows, more women (54\%) than men (41\%) are patrons. Both men and women identify themselves as never-users in approximately $8 \%$ of the cases, but men qualify as ex-users more than women ( $40 \%$ vs. $33 \%)$, showing a different trend towards disengagement by gender.

Younger segments show a closer relationship with public libraries. Particularly, patrons represent more than $60 \%$ of the individuals in age groups up to 49 years old, but just $45 \%$ among those aged 65 or more. Precisely those over 65 show the highest prominence of never-users $(22 \%)$, while the highest ratio of ex-users appears in the 50-64 group (46\%). Therefore, middle aged tend to disengage more than those up to 49 years old and the population 65 and over stand out as those who had never related to the public library. We observe a positive relationship between educational level and engagement with public libraries, with a maximum of $64 \%$ of patrons among those with tertiary studies.

Those with lower educational level stand out in never using a public library (19\%), while disengagement with libraries is greater among those with secondary studies (39\% are ex-users). Finally, students are the most engaged with public libraries (77\%), in opposition to retired and pensioners (48\%) who also are the most detached from the public service with $18 \%$ of never-users. Interestingly, employed and unemployed individuals declare attending the public library in a similar proportion than the average (around 55\%).

\section{Middle aged tend to disengage more than those up to 49 years old. The po- pulation 65 and over stand out as those who had never related to the public li- brary}

Whereas the interest of the research focuses on non-users, patrons were invited to rate the public library, an information that can be of interest for understanding the ex-users trajectory. All but four patrons answered the question, giving an average score of 8.3 points (standard deviation, 1.3 ) on a scale of 0 to 10 , with the most common rate being 8 (34\% of the answers). Of particular interest are the students, who gave the lowest rating (7.98), and pensioners, who gave the highest one (8.6). ${ }^{2}$

Results confirm the existing trends (CEO, 2015; Horrigan, 2016; Quick; Prior et al., 2013).

- First the gender dimension, with more users among women than men at any age.

- Second, the detachment from the libraries once full-time education finishes.

- Third, the reduced proportion of users among the older population, who seem to be particularly detached from

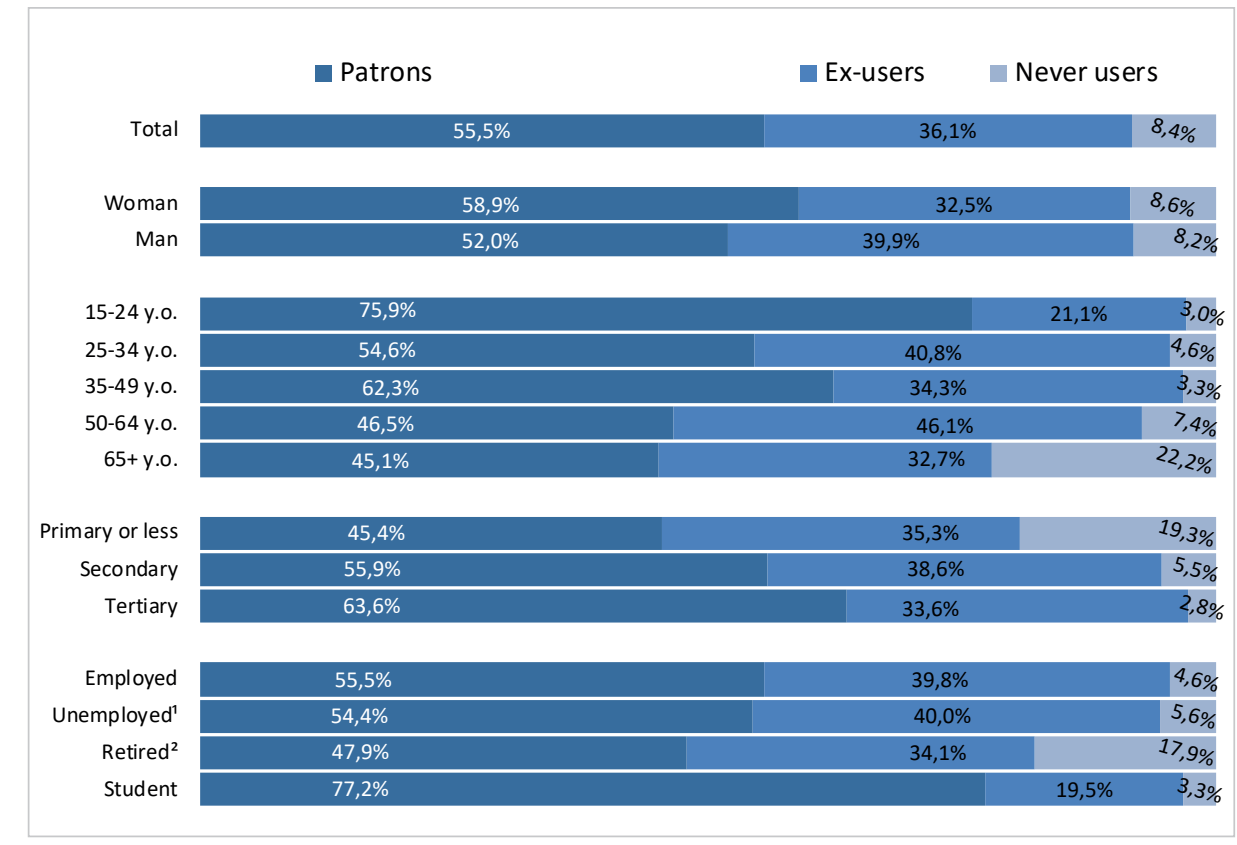

Figure 1. Use and non-use of public libraries broken by socio-demographic characteristics.

$\mathrm{N}=1205$, of which Patrons $=669$ and non-users $=536$ (ex-users $=435$, never-users $=101)$.

Statistically significant differences among groups at least at $5 \%$ level for all the variables (chi-square test). 1. Includes homemakers, 2. Includes pensioners. 
public libraries. Mostly retired, older people achieved lower educational levels than the average (Idescat, 2011); while in terms of cultural consumption, they belong to the low consumption type, which does not approach libraries (lermb, 2009).

Non-users, in addition, had a very good perception of the library, similar to patrons' evaluation in both Catalonia (CEO, 2015) and other places as Navarra (Hernández-Sánchez, 2016). Also similar to these two analyses are the results regarding students and retired people who, respectively, are more and less critical than the average.

\section{The image of the public library and the librarian among non-users}

In Catalonia, the library is identified mainly as a cultural facility $(47 \%)$, then as a resource for study (27\%); and finally as a leisure facility (15\%, see Figure 2$)$. Public libraries are far from being related to digital technology, an option only mentioned in $2 \%$ of the cases that we merged within the category Others (11\%).

The identification of the library as a cultural facility increases with age, getting over $50 \%$ among those 50 years old and over (see Figure 7, Annex), and with lower levels of education (primary studies or less, 50\%). The cultural dimension gets its maximum among retired people and employed individuals (49\% in both cases). In the other end, study becomes the most important dimension among the young ones (50\% in the age segment $15-24)$ and among students (57\%). The leisure dimension outdoes the average among those below 25 (19\%) and above 50 years old (with a maximum of $20 \%$ in the 50-64 group). Finally, the $65+$ and the retired are above the average in selecting the category "Others" $(21 \%$ and $20 \%$, respectively).

An open-ended question lead to the creation of four categories about the image of the librarian:

- First, professional characteristics relate to the activities carried out by librarians; e.g., the librarian gives advice, is methodical, or is organized.

- Second, personality traits relate to character or manners; e.g., the librarian is empathic, patient, enjoyable, or serious.

- Third, physical characteristics refer to comments about the aesthetic image; e.g., a librarian wears glasses, or has a bun.

- Fourth, the profession synthesized expressions related to how the work is considered; e.g., it is a good profession, unappreciated, or respectable.

As our interest is in understanding whether the image of librarians is positive or negative among non-users, we classified the assessments in the four categories (see Figure 3). Non-users mostly have a positive image of librarians (58\%) and a minority has a negative image (7\%). One out of four (27\%) expressed neither positive nor negative images and were classified under the label "Other", while one out of ten (10\%) did not answer.

In socio-demographic terms two dimensions stand out (Figure 8 , Annex). First, in terms of age, older people show the better opinion about librarians, with those above 50 expressing the highest positive and the lowest negative descriptions (at least $63 \%$ and $5 \%$ or less, respectively). In contrast, those with highest negative perceptions are young adults aged 25 to 34 (11\%). And second, in terms of the relationship with the labor market, unemployed show the worst opinion, with up to $11 \%$ pointing towards negative images. On the other end, retired individuals have the better one $(68 \%$ have a positive image), while students stand out in mentioning neutral opinions (43\%).

Results show that the library is mostly seen as either a cultural institution or a as a place for study. Interestingly, older people and retired individuals seem to link the library with culture in the sense of culture as an antithesis to leisure (Rojek, 1999); while students and younger people are the ones who most identify the library as a place for studying. This association of the library as an institution for education -rather than for leisure activities- is coincident with the study of users of Spanish public libraries (Fundación Germán Sánchez Ruipérez, 2009). Beyond the cultural dimension, the library is seen as a leisure facility in some locations (Sbaffi; Rowley, 2015). This is the case of some groups of non-users in Catalonia. Even though those who seem to identify the library with free-time activities stay as a minority, this result suggests that the library could turn into a closer public facility.

The image of the library is not homogenous. For instance, it can be related to social welfare services in some contexts

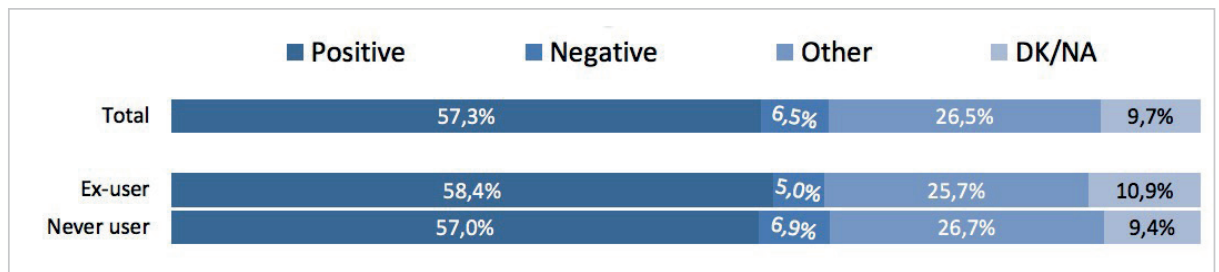

Figure 3. Image of librarians among non-users.

$\mathrm{N}=536$. No statistically significant differences at usual levels among ex-users and never-users (chi-square test). Others include opinions on the profession of librarian (not on the person) that could be either positive or negative, and opinions on the librarian that could not be clearly classified as positive or negative. 
(Horrigan, 2016; Sbaffi; Rowley, 2015), a dimension that does not stand out in the obtained results. This is the case in the United Kingdom, where public libraries are seen as agencies for social issues, with support services for job-seeking, information on health issues, or social benefits. In contrast, in Italy they are more commonly seen as cultural facilities (Sbaffi; Rowley, 2015), as they offer entertainment and leisure programs, in an attempt to deal with the lack of accessible and culturally stimulating entertainment for everyone, and provide basic services such as reading newspapers free of charge or support for study (Consonni, 2010).

\section{Public libraries are far from being rela- ted to digital technology}

Finally, Catalan non-users mostly express positive opinions of librarians, which contrasts with the general trend towards negative perceptions of the profession (Vassilakaki; Moniarou-Papaconstantinou, 2014). However, given the provided descriptions, this does not necessarily mean they have knowledge of the profession.

\section{Going (back) to the library? Potential patrons}

Two questions addressed the motivations that would make non-users visiting the public library -either again or for the first time. First, an open question all non-users were invited to answer. Second, those who provided a reason in the former question were invited to rate the importance of the main motivations the bibliography discusses (Cañibano; Bargero, 2004; Sin; Kim, 2008; Consonni, 2010; Schleihagen; Ehmig, 2012). Finally, we use the school library as a proxy of a factor that could explain the relationship of nonusers with the public library, as it might constitute a seed to engage individuals with public libraries (Schleihagen; Ehmig, 2012). While in the two first questions we found no statistically significant differences between ex-users and never-users, such differences arose in the case of the experience with the school library.

First, the most important motivation that would bring non-users (back) to the public library are personal reasons $(37 \%)$, and having no time stands out as its most important subcategory (17\%) (Figure 4, and Table 1 in the Annex). Secondly, 35\% of non-users would have no reason to visit (again) the library, no matter the changes there could be. Of comparatively lower relevance are improvements in infrastructure (13\%), collection $(12 \%)$ or in services $(6 \%)$. A remaining $5 \%$ provided other reasons.

The most important aspect that could make potential users paying (back) a visit to the library is the human factor. Expressed as good per- sonal attention, stands out with 9 out of 10 points (Figure 5). A cluster of four factors ranks second with values around 8.5. Three relate to the infrastructure (comfort, computers and internet connection, and location), while one is a traditional library services (good offer of novelties). In third place, five factors cluster around 7.9 points. They relate to services and activities (appealing services and variegated activities), and to the affordances the infrastructure allows (teamwork and meetings). Closing the list, the cafeteria appears as the least significant factor, being the only one rated below 7 .

\section{The library is mostly seen as either a cul-} tural institution or a as a place for study

Finally, half of non-users declared either not having had a school library $(23 \%)$ or having a bad memory of it $(27 \%)$ (Figure 6). Interestingly, never-users had no school library in more occasions than ex-users (38\% versus $20 \%$ ), a result that points towards the importance of having access to a library during childhood to create a habitude.

Positive memories of the library quality decrease with age (Figure 9, Annex). Also, the oldest age group and the retired individuals are those who most frequently mention not having a school library (41\% in both cases). Positive memories, conversely, increase with educational level, while students stand out for having the best memories of the school library (68\%).

The most relevant result is that more than one third of nonusers seem to be totally disengaged from the public library, as they find no reason that would make them visiting the library (again) regardless of the changes they could happen. This evidence is in line with CEO (2015), that reports a $23 \%$ of the adult population in Catalonia not being interested in visiting the library -regardless if they define themselves as users or not. In general, lack of interest constitutes a major barrier to use (Booth, 1993; Coker, 1993; Green, 1994). The

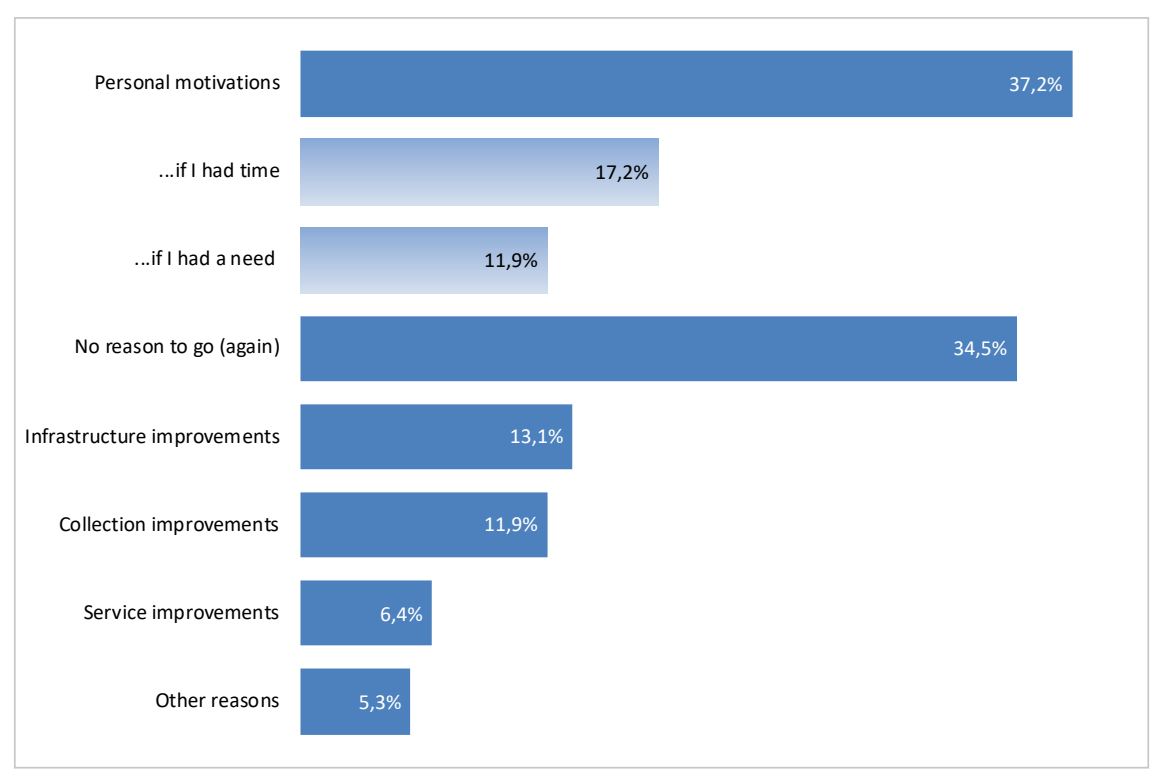

Figure 4. Motivations for visiting (again) the public library among non-users.

$\mathrm{N}=487$. Non-exclusive categories. Main categories ( ) and selected subcategories ( ) reported. 


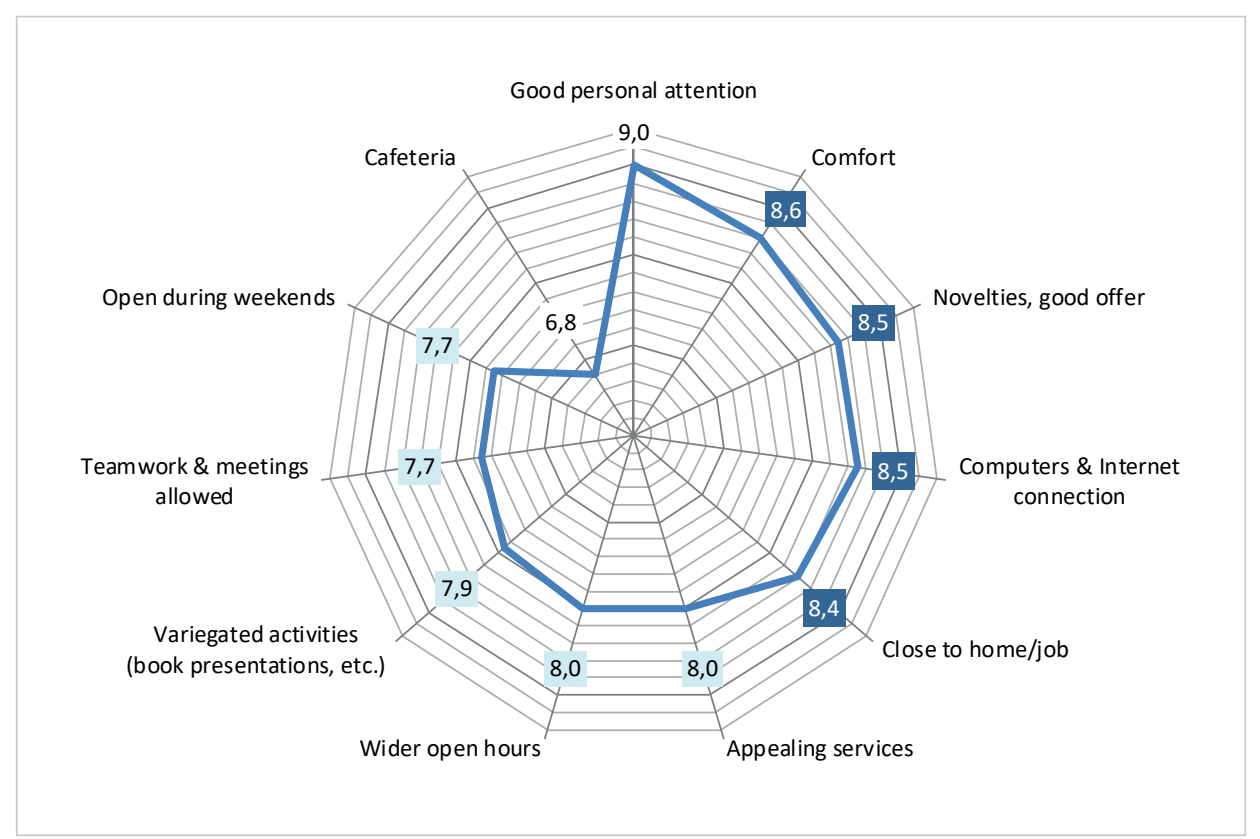

Figure 5. Factors that could make non-users go to a public library (again), rated from 0 (unimportant) to 10 (very important).

$\mathrm{N}=368$. The question was only addressed to those who answered the previous question (excluded those who declared not having any reason to go to the public library). Same colors ( \& \& ) indicates clustered categories (statistically significant differences with other categories but not among them at usual levels), while non shadowed categories are statistically different to all the rest (T-test for related samples).

tion in the obtained results, a dimension that points beyond infrastructure, activities and collections.

Finally, results confirm the positive relationship between having a school library and the attachment to the public library. In this sense, international analyses relate positive attitudes towards learning, motivation and autonomous reading to those who had libraries at schools (Miret; Baró, 2016); a dimension that shapes the willingness to visit public libraries.

\section{Conclusions: towards UX recommendations}

The main goal of the paper is to provide information to support the design and decision making towards the engagement of the half of the population not using the library in Catalonia from the

library seems to be far from the imaginary of one third of the Catalan non-users, and a way to break with this image and bring ex and never-users to the library is making them aware that they are not only welcome to the library but they are the ones that should design it (Booth, 1993). Results also show the importance of the lack of time for being disengaged from the library, echoing existing empirical evidence (e.g. Schleihagen; Ehmig, 2012; Evjen; Auduson, 2009; Hernández-Sánchez, 2013).

\section{Older people show the better opinion about librarians}

Factors that would make potential users visiting (back) the library are diverse in the case of Catalonia. In general terms, this is in line with Artal (1999), who found that most highly rated facilities in public libraries were those for children (storytelling, dedicated spaces for kids, or school-library relationship), the variegated range of entertainment materials (digital or in paper) and a pleasant and versatile space. Of particular interest is the importance of good personal atten- perspective of the user experience (UX) framework. UX design is linked with people, the user is always in mind or even participating in finding solutions which have to be useful, easy and attractive.

\section{Libraries are seen as institutions for edu- cation, rather than for leisure activities}

In order to find the most valuable information from potential users, a non-user research study based on a representative survey of the Catalan population aged 15 and over was carried out. It provided information regarding characteristics, preferences, desires, opinions and perceptions of public library non-users, and included a section where patrons rated the library.

In general, the image of the public library is very good. Users are highly satisfied despite the budgetary reductions faced by this public service (Hernández-Sánchez; Arroyo-Vázquez, 2014). However, one third of non-users have no motivation for visiting a public library even though a majority are formerly users.

Results show that different design strategies must be defined towards ex-users and never-users to attract them (back) to the library as both their characteristics, preferences and perceptions on the public library are different. Particularly, the li-

Figure 6. Assessment of the library school quality by non-users. 
brary seems to be far from the imaginary of one third of the Catalan non-users, and a way to break with this image and bring (back) potential users to the library is making them aware that they are not only welcome to the library but they are the ones that should design it (Booth, 1993).

Ex-users have had a previous experience of the public library at least one year ago and they have stop using it. They are more prominent among those with higher educational level and for population up to 64 years old, most part of non-users are ex-users. Individuals seem to stop using the public library when they end their educational period; with disengagement affecting more men than women. Those with tertiary education completed are the ones who most use the public library, but among them the percentage of ex-users is comparatively high as well; and they are the group who most associate public library with study (only surpassed by those who define themselves as students). We suggest that there is a disengagement process during life trajectory, that the role of the school library is key and that the experience during the educational period is critical to retain them as users one they start participating in the labor market. Of particular relevance here is that students are the most critical user collective therefore we foresee the need to establish specific activity plans and services for consolidating the library as an habit in their leisure time.

\section{Results confirm the positive relationship between having a school library and the attachment to the public library}

Never-users stand out among older individuals (65 years and over) retired, and lower education levels. Both older and retired individuals are those who attend the least to the library, but when they use it they are the most satisfied with the service. Older individuals not using the library stand out for having the most positive opinion of librarians. They are also those who most times mention not having a library at school, and mainly identify the public library with culture. It seems, therefore, that these groups perceive the public library as a positive infrastruc- ture, good for the society but not a place they would think they could use. Actions for making feel them as at home should be designed, both in terms of services and in terms of physical spaces, as well as cooperating with the social services that accompany the senior collective. Of particular relevance would be enhancing the leisure dimension among these collectives.

\section{Different design strategies must be defi- ned towards ex-users and never-users to attract them (back) to the library}

The present paper offers views coming from a quantitative approach. The survey is representative, but it faces the usual limitations of structured questionnaires. To get a deeper understanding of non-users, and aiming at new ideas on products and services the public library could offer them, it is necessary to complement the research with a qualitative approach. Therefore we have conducted a characterization of patrons, never-users and former users to create paradigmatic individuals to support the design of products and services appropriate to people's needs and their expectations. Furthermore focus groups with the paradigmatic user personas has been performed during 2017 (Ferran-Ferrer et al., 2018) following a more qualitative and ethnographic approach (Khoo et al., 2014).

\section{Acknowledgements}

This study was made possible by the Library Service of the Government of Catalonia, and was part of the activities related to the Year of the Library (2015). We thank Daniel Ibáñez-Vidal for his support in the initial data analysis.

\section{Notes}

1. We do not report on other dimensions that show no relationship with public libraries use. First, mother language (Catalan, Spanish or both). Second, the size of the town or city of residence (four categories, from $<=10.000$ inhabitants to $>500.000$ ). And third, the province of residence (Barcelona, Girona, Lleida, Tarragona).

2. Differences are statistically significant at least at $5 \%$ level. 


\section{Annex}

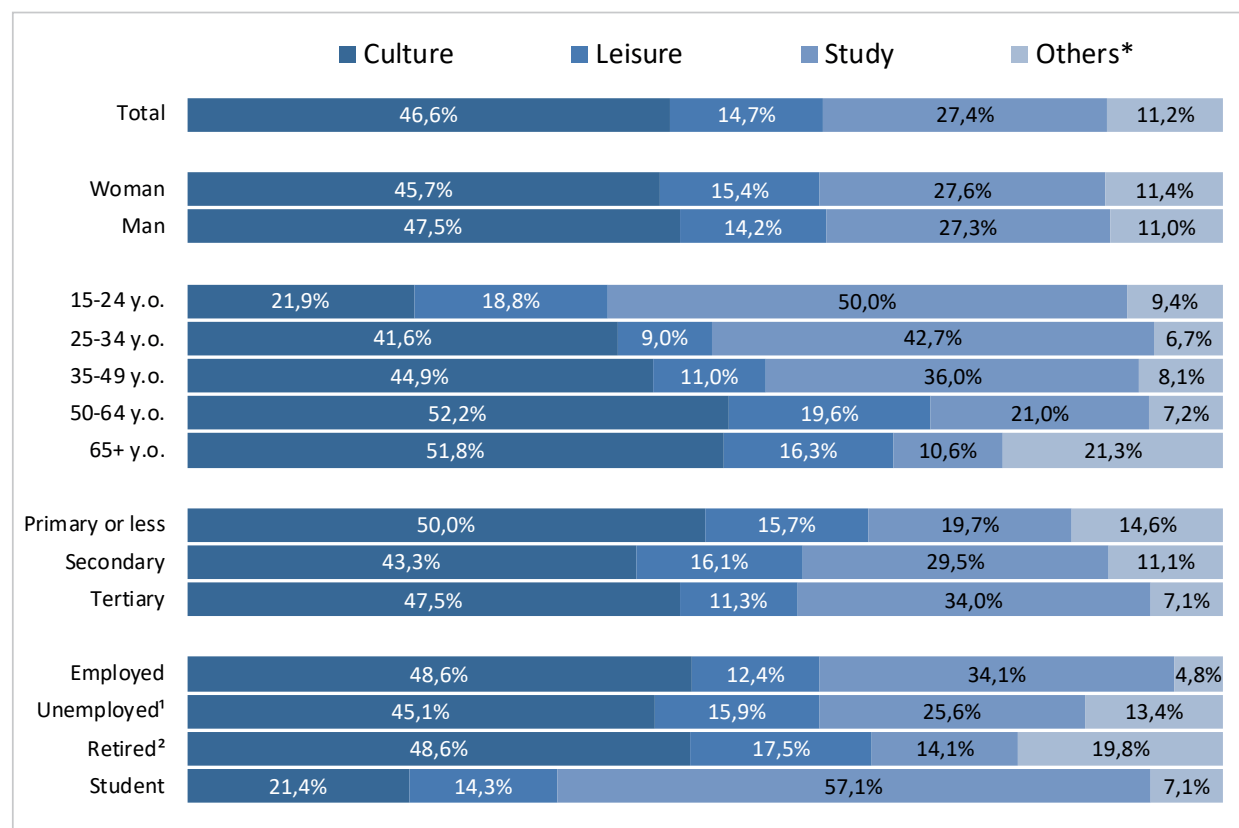

Figure 7. The image of the public library among non-users, broken by socio-demographic characteristics.

$\mathrm{N}=536$. * Includes the original categories "Technology", "Others and DK/NA.

Statistically significant differences among groups at least at $5 \%$ level for all the variables (chi-square test) except for Gender. 1. Includes homemakers, 2. Includes pensioners.

Table 1. Motivations for visiting (again) the public library among non-users

\begin{tabular}{|c|c|}
\hline Personal motivations & $37,2 \%$ \\
\hline If I had time & $17,2 \%$ \\
\hline If I had a need (either unspecific or related to job, studies or other interest) & $11,9 \%$ \\
\hline $\begin{array}{l}\text { Other (includes not having enough books, not having other kind of libraries, liking } \\
\text { reading, and not having health/age issues) }\end{array}$ & $9,9 \%$ \\
\hline No reason/motivation to go (again) & $34,5 \%$ \\
\hline Infrastructure improvements & $13,1 \%$ \\
\hline Location (closer to home / work) & $5,1 \%$ \\
\hline Comfort & $4,7 \%$ \\
\hline $\begin{array}{l}\text { Other (includes having a cafeteria, } \\
\text { allowing teamwork, and having leading ICTs) }\end{array}$ & $4,1 \%$ \\
\hline Collection improvements & $11,9 \%$ \\
\hline Good novelties offer & $8,8 \%$ \\
\hline Internet already has all the information & $3,1 \%$ \\
\hline Service improvements & $6,4 \%$ \\
\hline Appealing services & $3,5 \%$ \\
\hline Wider open hours (but not on weekends) & $2,5 \%$ \\
\hline Better staff attention & $0,4 \%$ \\
\hline Communication improvements & $0,0 \%$ \\
\hline If I knew the location & $0,0 \%$ \\
\hline If I knew how it works & $0,0 \%$ \\
\hline Other reasons & $5,3 \%$ \\
\hline
\end{tabular}

$\mathrm{N}=487$. Non-exclusive categories. Total percentages of main categories do not necessary add the same than the aggregation of sub-categories. 


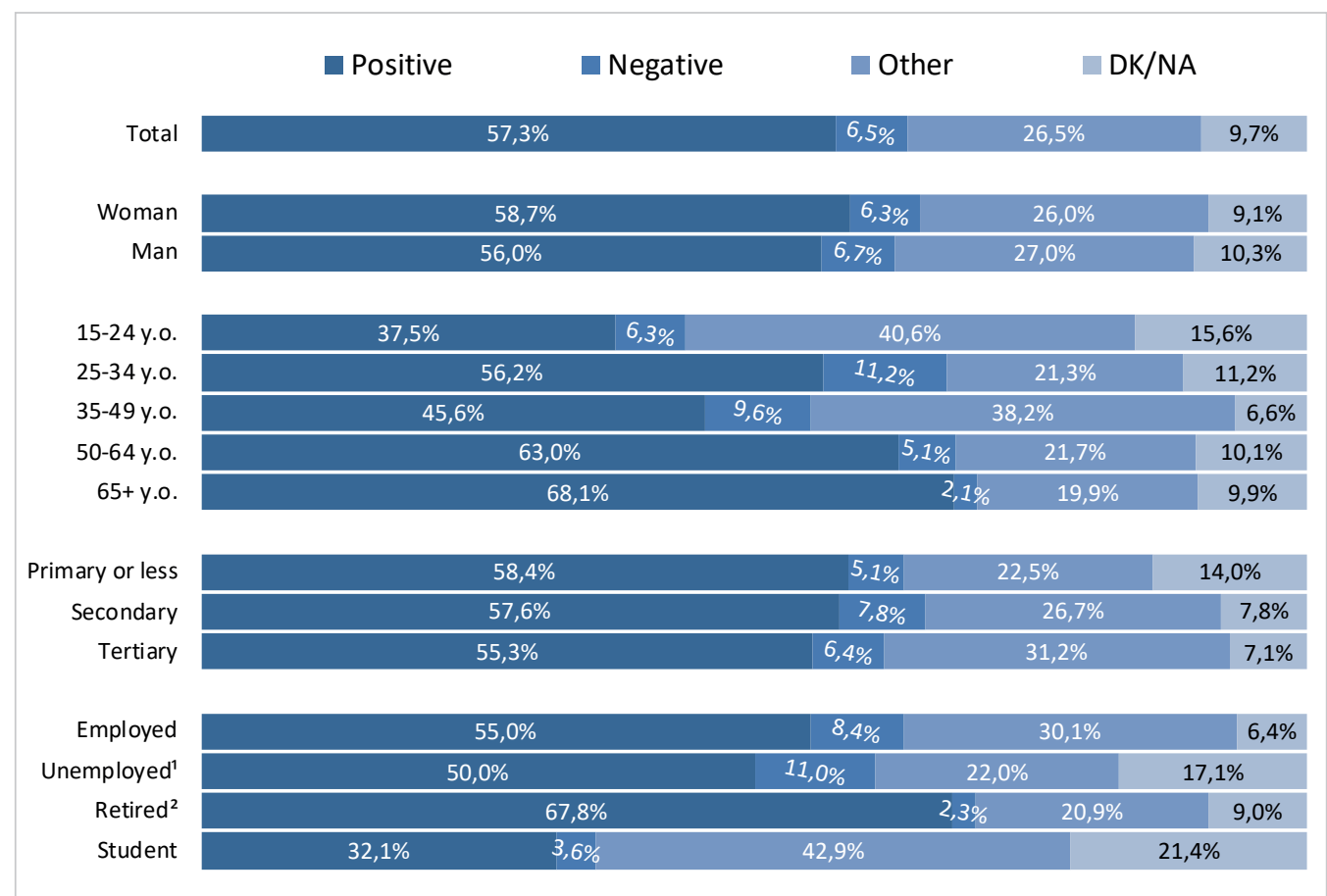

Figure 8. The image of librarians among non-users, broken by socio-demographic characteristics.

$\mathrm{N}=536$.

Statistically significant differences among groups at least at $5 \%$ level for all the variables (chi-square test) except for Gender and Level of studies. 1. Includes homemakers, 2. Includes pensioners.

Others include opinions on the profession of librarian (not on the person) that could be either positive or negative, and opinions on the librarian that could not be clearly classified as positive or negative.

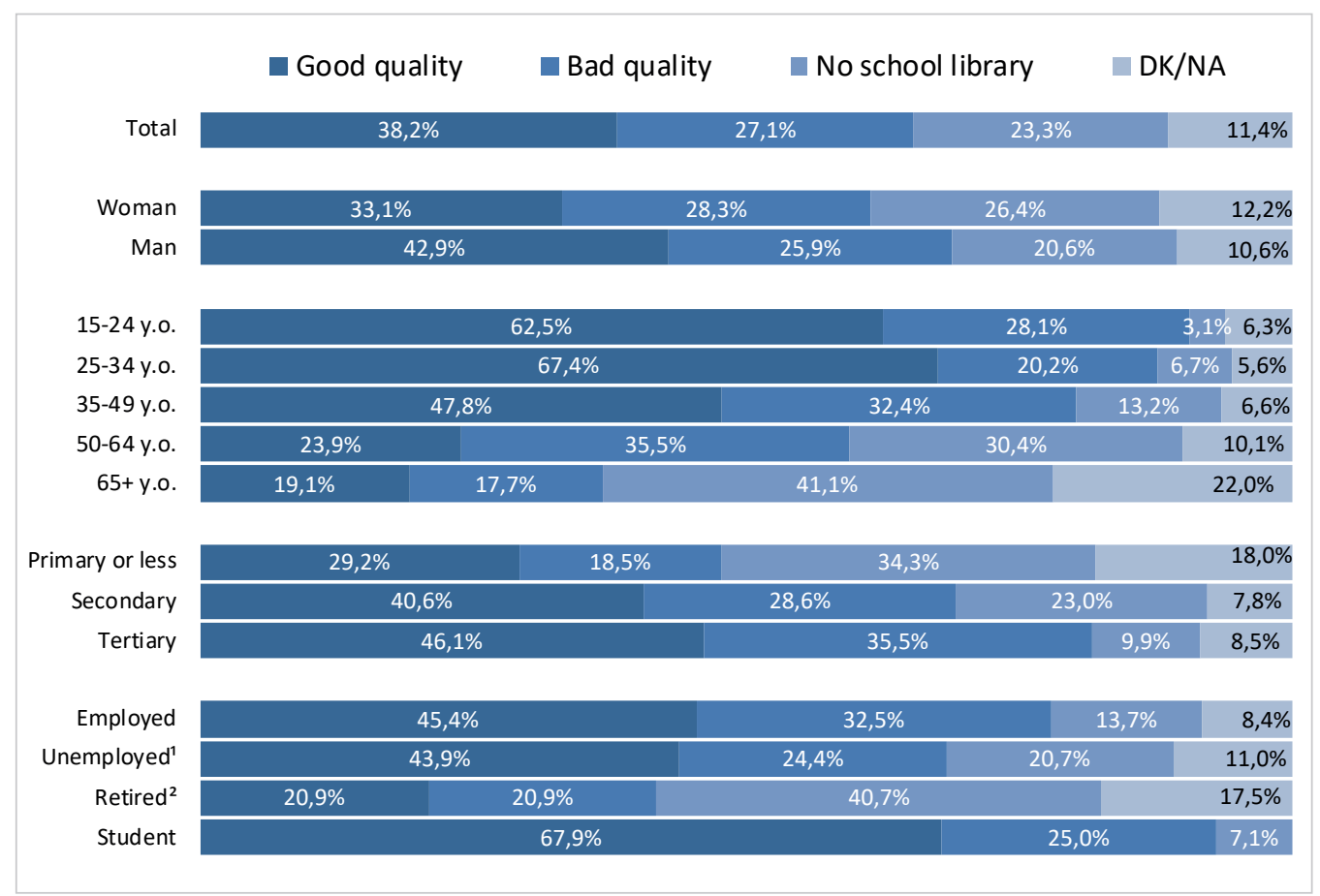

Figure 9. Assessment of the library school quality by non-users, broken by socio-demographic characteristics.

$\mathrm{N}=536$.

Statistically significant differences among groups at least at $5 \%$ level for all the variables (chi-square test) except for Gender. 1. Includes homemakers, 2. Includes pensioners. 


\section{References}

Anglada, Lluís (2014). "Are libraries sustainable in a world of free, networked, digital information?". El profesional de la información, v. 23, n. 6, pp. 603-611.

http://doi.org/10.3145/epi.2014.nov.07

Artal, Carmen (1999). La biblioteca pública vista pels ciutadans. Informe de l'estudi realitzat a tres ciutats 199899. Barcelona: Fundación Bertelsmann; Àrea de Cultura de la Diputació de Barcelona. ISBN: 8493093432

Azqueta-Ledo, Cristina; Ferrández-Cañadell, Eva (2015). Balanç de Govern, Departament de Cultura 2011/2015. Vol I. Barcelona: Generalitat de Catalunya, Departament de Cultura. https://goo.gl/r5R8HJ

Booth, Jennifer (1993). "The library's image: does your library have you appeal?". Library management, v. 14, n. 2, pp. 11-14.

http://doi.org/10.1108/01435129310026111

Bryant, Antony; Charmaz, Kathy (eds.) (2007). The SAGE Handbook of grounded theory. Los Angeles: Sage. ISBN: 978 1849204781

Cañibano, Analía; Bargero, Patricia (2004). "Los no usuarios: ¿cómo llegar a ellos en nuestras comunidades?". In: IFLA conf procs, pp. 1-14.

https://archive.ifla.org/IV/ifla 70/papers/163s-Canibano_ Bargero.pdf

CEO (2015): Òmnibus de la Generalitat de Catalunya 2014-3. REO 773. Generalitat de Catalunya: Centre d'Estudis d'Opinió. http://ceo.gencat.cat/es/estudis/registre-estudis-dopinio/ estudis-dopinio-ceo/omnibus/detall/index.htm/?id=5248

Clark, Christina (2010). Linking school libraries and literacy: Young people's reading habits and attitudes to their school library, and an exploration of the relationship between school library use and school attainment. Londres: National Literacy Trust.

https://goo.gl/dhCwEh

Coker, Susanne (1993)."Libraries versus users? How and how not to deter library users". Library management, v. 14, n. 2, pp. 24-31.

https://doi.org/10.1108/EUM0000000000844

Conecta (2016). Hàbits de lectura i compra de llibres a Catalunya 2015. Informe de resultats. Generalitat de Catalunya, 123 pp. https://issuu.com/icec_generalitat/docs/h__bits_de_ lectura_a_catalunya_2015

Connaway, Lynn-Silipigni (ed.) (2015). The library in the life of the user: Engaging with people where they live and learn. Dublin, Ohio: OCLC Research.

http://www.oclc.org/content/dam/research/publications/2015/ oclcresearch-library-in-life-of-user.pdf

Consonni, Chiara (2010). "Non-users' evaluation of digital libraries: A survey at the Università degli Studi di Milano". IFLA, v. 36, n. 4, pp. 325-331.

https://goo.gl/jDZhDq

Departament de Cultura (2017). Estadístiques Culturals de Catalunya 2017. Generalitat de Catalunya. ISSN: 2013-3863 http://dadesculturals.gencat.cat/web/.content/sscc/gt/ arxius_gt/ECC-2017.pdf

DIBA (2012). Informe sobre la població no usuària de les biblioteques de la XBM: resum executiu. Versió 2, 17/05/2012. Barcelona: Diputació de Barcelona. Servei d'Avaluació i Qualitat. Àrea de Presidència.

https://www.diba.cat/documents/16060163/33955494/ d+informe_resum_estudi_no_usuaris.pdf

Evjen, Sunniva; Audunson, Ragnar (2009). "The complex library". New library world, v. 110, n. 3/4, pp.161-174. http://doi.org/10.1108/03074800910941356

Ferran-Ferrer, Núria; Fernández-Ardèvol, Mireia; Nieto, Javier; Fenoll, Carme (2016). Estudi de persones no-usuàries de biblioteca pública.

http://biblioteques.gencat.cat/web/.content/tematic/ persones_no_usuaries.pdf

Ferran-Ferrer, Núria; Fernández-Ardèvol, Mireia; Nieto, Javier; Fenoll, Carme (2018). "Marc, Maria y David: el diseño de experiencia de usuario (UX) aplicado a la biblioteca pública". BiD, n. 40.

http://bid.ub.edu/es/40/ferran.htm

Fundación Germán Sánchez Ruipérez (2009). Opiniones y actitudes de los usuarios de las Bibliotecas Públicas del Estado, 2008.

http://hdl.handle.net/10421/1621

Gallo-León, José-Pablo (2015). "La biblioteca es servicio (y en ello está nuestro futuro)". El profesional de la información, v. 24, n. 2, pp. 87-93.

http://dx.doi.org/10.3145/epi.2015.mar.01

Green, Tracey (1994). "Images and perceptions as barriers to the use of library staff and services". New library world, v. 95, n. 7, pp. 19-24.

http://doi.org/10.1108/03074809410070520

Hair, Joseph F. (2010). Multivariate data analysis: A global perspective $\left(7^{\text {th }}\right.$ ed.). Upper Saddle River [etc.]: Pearson. ISBN: 9780138948580

Hernández-Sánchez, Hilario (2013). Servicios bibliotecarios para el siglo XXI: ciudadanos, usuarios y expertos opinan sobre los servicios de biblioteca pública de la CAPV. http://www.liburuklik.euskadi.eus/handle/10771/26106

Hernández-Sánchez, Hilario (2016). El valor de las bibliotecas. Estudio de impacto socioeconómico de las Bibliotecas de Navarra. Madrid: Consejo de Cooperación Bibliotecaria. http://www.elvalordelasbibliotecas.es/es/informe

Hernández-Sánchez, Hilario; Arroyo-Vázquez, Natalia (2014). "Efectos de la crisis económica en las bibliotecas españolas". El profesional de la información, v. 23, n. 2, pp. 158-164. http://dx.doi.org/10.3145/epi.2014.mar.08

Horrigan, John B. (2016). Libraries 2016. Pew Research Center, September.

http://www.pewinternet.org/2016/09/09/2016/Libraries-2016

Idescat (2011). Nivell d'instrucció de la població de 16 anys $i$ més. Per sexe i grups d'edat. Catalunya.

https://www.idescat.cat/economia/inec tc $=3 \& i d=d c 02$ 
lermb (2009). "Tipologies de consum i pràctiques culturals a Catalunya 2006". Estadística-Fulls de cultura i comunicació, n. 24, 10 pp.

http://dadesculturals.gencat.cat/web/.content/sscc/gt/ arxius_gt/fl_024_tipologies_generals_consum.pdf

IFLA (International Federation of Library Associations and Institutions). Section of public libraries (2001). Public Library Service: IFLA/Unesco Guidelines for development. KG Saur. Translation into Catalan by Cobdc.

http://www.cobdc.org/publica/directrius/IFLA_publiques.pdf

Johnson, Larry; Adams-Becker, Samantha; Estrada, Victoria; Freeman, Alex (2015). NMC Horizon report: 2015 Library edition. Austin, Texas: The New Media Consortium. ISBN: 9780996852753

http://cdn.nmc.org/media/2015-nmc-horizon-reportlibrary-EN.pdf

Juárez-Urquijo, Fernando (2015). Biblioteca pública. Mientras llega el futuro. Barcelona: Ed. UOC, Col. El profesional de la información, n. 31, 159 pp. ISBN: 9788490646663

Khoo, Michael; Rozaklis, Lily; Hall, Catherine (2012). "A survey of the use of ethnographic methods in the study of libraries and library users". Library \& information science research, v. 34, n. 2, p. 82-91.

https://doi.org/10.1016/j.lisr.2011.07.010

Levien, Roger E. (2011). Confronting the future. Strategic visions for the $21^{\text {st }}$ public library. American Library Association, Office for Information Technology. Policy brief, 4.

http://www.foresightfordevelopment.org/sobipro/downloadfile/46-463/54

Llei 4/1993, de 18 de marzo, del Sistema Bibliotecari de Catalunya (DOGC, n. 1727, de 29.3.1993).

http://portaldogc.gencat.cat/utilsEADOP/AppJava/ PdfProviderServlet?version $/ d=1234087$

Luthmann, Abigail (2007). "Librarians, professionalism and image: stereotype and reality". Library review, v. 56, n. 9, pp. 773-780.

http://doi.org/10.1108/00242530710831211

McCarthy, Grace (1994). "Getting to know your non-users". Library management, v. 15, n. 4, pp. 30-34.

http://doi.org/10.1108/01435129410060338

Miret, Inés; Baró, Mònica (2016). “Bibliotecas escolares a pie de página". In: Millán, José-Antonio (coord.). La lectura en España: informe 2017. Madrid: Federación de Gremios de Editores, pp. 127-138.

http://www.fge.es/lalectura/2017

Nieters, Jim; Gabriel-Petit, Pabini (2014). "The future of UX leadership: Radical transformation". UXmatters. https://shar.es/1jU935

Norman, Don; Nielsen, Jacob (2014). The definition of user experience.

https://www.nngroup.com/articles/definition-user-experience

Quick, Susannah; Prior, Gillian; Toombs, Ben; Taylor, Luke; Currenti, Rosanna (2013). "Cross-European survey to measure users' perceptions of the benefits of ICT in public libra- ries". Bill \& Melinda Gates Foundation. https://goo.gl/fwUzTV

Reidsma, Matthew (2015). "More than usable. Library services for humans". In: UXLibs conference, Cambridge. https://matthew.reidsrow.com/articles/134

Rojek, Chris (1999). Leisure and culture. Springer. ISBN: 978 0230287563

Sbaffi, Laura; Rowley, Jennifer (2015). "Public libraries and nonusers: A comparison between Manchester and Rome". Journal of librarianship and information science, v. 47, n. 2, pp. 104-116. http://doi.org/10.1177/0961000613503679

Schleihagen, Barbara; Ehmig, Simone (2012). Causes and reasons for the non use of public libraries in Germany. German Library Association.

http://www. readingworldwide.com/fileadmin/dokumente/ Non_use_of_public_libraries_final_English_Handout.pdf

Schmidt, Aaron; Etches, Amanda (2014). Useful, usable, desirable: Applying user experience design to your library. Chicago: American Library Association (ALA). ISBN: 9780 838912263

https://www.tandfonline.com/doi/abs/10.1080/194112 $6 X .2015 .1029781$

Servei de Biblioteques de la Generalitat de Catalunya (2017). Sistema de Lectura Pública: Balanç 2016.

https://goo.gl/U9Aifq

Sin, Sei-Ching-Joanna; Kim, Kyung-Sun (2008). "Use and non-use of public libraries in the information age: A logistic regression analysis of household characteristics and library services variables". Library \& information science research, v. 30, n. 3, pp. 207-215.

https://doi.org/10.1016/j.lisr.2007.11.008

Technical Committee ISO-TC 46 (2014). ISO 11620:2014 Information and documentation: Library performance indicators. Geneva: International Organization for Standarization.

https://www.iso.org/obp/ui/\#iso:std:iso:11620:ed-3:v1:en

Togores, Rosa (2014). El valor de las bibliotecas públicas en la sociedad: el caso de la Red de Bibliotecas Municipales. Versión reducida. Diputació de Barcelona, 38 pp. http://www.diba.cat/documents/16060163/22275360/ valor_social_bibliotequesXBM_cast.pdf

Toner, Lisa-Jane (2008). "Non-use of library services by students in a UK academic library". Evidence based library and information practice, v. 3, n. 2, pp. 18-31.

http://ejournals.library.ualberta.ca/index.php/EBLIP/ article/view/1330/1241

Unesco (1994). Manifiesto sobre la biblioteca pública. París: Unesco.

http://unesdoc.unesco.org/images/0011/001121/112122so.pdf

Vassilakaki, Evgenia; Moniarou-Papaconstantinou, Valentini (2014). "Identifying the prevailing images in library and information science profession: is the landscape changing?". New library world, v. 115, n. 7/8, pp. 355-375.

http://doi.org/10.1108/NLW-03-2014-0029 